\title{
Vocal Response of Oriental Magpie Robin (Copsychus saularis) to Urban Environmental Factors in Peninsular Malaysia
}

\author{
(Respons Vokal Murai Kampung (Copsychus saularis) kepada Faktor Persekitaran Bandar di Semenanjung Malaysia)
}

\author{
Shafinaz Hanafi, ChOng LeOng PUAN*, SReEtheran MaruthaVEeran \& KoK LoONG YeOnG
}

\begin{abstract}
Anthropogenic noise and changes in environmental gradients resulted from urbanisation have been shown to alter vocalisation of urban birds in previous studies. This study examined the vocalisation of the Oriental Magpie Robin (Copsychus saularis; locally known as Murai Kampung) in relation to anthropogenic noise and environmental factors in the urban, suburban and rural areas in Peninsular Malaysia. We measured four ambient factors (i.e. ambient noise, temperature, relative humidity and light intensity) and two landscape factors (i.e. distance to building and distance to major roads) between January and June 2017 from six locations. A total of 147 recordings comprising territorial songs of the bird were obtained and transcribed into spectrograms. Six parameters, namely low frequency, high frequency, frequency ranges, length of strophe, number of elements per strophe, and time interval between strophes were derived from spectrograms for each recording. In urban areas, low frequency of the songs was found to have increased significantly as compared to those recorded in suburban and rural areas. The difference in noise, temperature and relative humidity in urban and suburban environment had led to both single and interaction effects towards the Oriental Magpie Robin's song parameters, i.e. low frequency, length of strophe, time interval between strophes and number of elements per strophe. The results evidenced the ability of the Oriental Magpie Robin in regulating and altering their song structure according to its surrounding environment. This implies its vocal plasticity which is important in ensuring the efficiency in transmission of songs and is likely to explain why the bird is less susceptible to urbanisation.
\end{abstract}

Keywords: Ambient and landscape factors; bird species; frequency; urbanisation; vocalisation

ABSTRAK

Kajian terdahulu telah menunjukkan bahawa bunyi antropogenik dan perubahan faktor persekitaran yang berpunca daripada pembandaran telah mengubah penyuaraan burung bandar. Kajian ini bertujuan untuk meneliti perkaitan antara penyuaraan Murai kampung (Copyschus saularis) dan bunyi antropogenik serta faktor persekitaran di kawasan bandar, pinggir bandar dan luar bandar di Semenanjung Malaysia. Kami mengukur empat faktor persekitaran (iaitu bunyi persekitaran, suhu, kelembapan relatif dan keamatan cahaya) dan faktor landskap (iaitu jarak ke bangunan dan jarak ke jalan utama) antara bulan Januari dan Jun 2017 di enam lokasi terpilih. Sejumlah 147 rakaman yang mengandungi nyanyian wilayah burung tersebut telah diperoleh dan ditukarkan kepada spektogram. Enam parameter iaitu frekuensi rendah, frekuensi tinggi, julat frekuensi, panjang strof, bilangan unsur per strof dan selang masa antara strof telah dihasilkan daripada spektrogram untuk setiap rakaman. Di bandar, adalah didapati bahawa frekuensi rendah telah meningkat secara ketara berbanding dengan di kawasan pinggir bandar dan luar bandar. Perbezaan bunyi antropogenik, suhu dan kelembapan relatif di bandar dan pinggir bandar telah menyebabkan kesan tunggal dan kesan interaksi terhadap parameter nyanyian burung Murai, iaitu frekuensi rendah, panjang strof, selang masa antara strof dan bilangan unsur dalam setiap strof. Hasil kajian ini telah membuktikan keupayaan Murai kampung untuk mengawal serta mengubah struktur nyanyiannya berdasarkan kepada keadaan persekitaran. Ini juga menunjukkan keplastikan vokal burung tersebut adalah penting untuk menjamin keberkesanan nyanyian dan ini juga menjelaskan mengapa nyanyian burung Murai kampung adalah kurang dipengaruhi oleh keadaan perbandaran.

Kata kunci: Faktor ambien dan landskap; kekerapan; penyuaraan; perbandaran; spesies burung

\section{INTRODUCTION}

Malaysia is one of the countries in Southeast Asia that has undergone rapid urbanisation over the last half of a century. In 2010, Kuala Lumpur and Putrajaya have successfully in achieving $100 \%$ urban population by means of having all their residents living in urban areas (Hasan \& Nair 2014). However, rapid and unplanned urban growth is often not sustainable and can threaten biodiversity (Faeth et al. 2011; McKinney 2006; Puan et al. 2019). Undeniably, urban areas are a source of pollution (Seress \& Liker 2015). In terms of noise pollution, noise level at several areas in Malaysia have exceed the limits set by World Health Organisation (WHO) (i.e. 55.0 dBA for daytime and 45.0 dBA for night time) (World Health Organisation 1999) 
and Department of Environment (DOE), Malaysia (i.e. 60.0 $\mathrm{dBA}$ for daytime and 45.0 dBA for night time (Department of Environment Malaysia 2007). For birds that rely on vocalisation for territorial defence, searching for a mate and communication, anthropogenic noise has been found to affect their vocalisations (Lowry et al. 2013; Luther et al. 2016; Mendes et al. 2011; Potvin et al. 2011) and even reproductive rate (Halfwerk et al. 2011).

Past studies have demonstrated that bird species altered their vocalisations in response to anthropogenic noise include House Finch (Carpodacus mexicanus) in Mexico (Bermúdez-Cuamatzin et al. 2009), Great Tit (Parus major) in Netherlands (Halfwerk and Slabbekoorn, 2009), Europe Blackbird (Turdus merula) in Spain (Mendes et al. 2011), Silvereye (Zosterops lateralis; Potvin et al. 2011) and Noisy Miner (Manorina melanocephala; Lowry et al. 2013) in Australia, Ash-throated Flycatcher (Myiarchus cinerascens; Francis et al. 2010) and Whitecrowned Sparrow (Zonotrichia leucophrys; Luther et al. 2016) in North America as well as White-breasted Whistler (Pachycephala lanioides) in Europe, North America and Australia (Hu \& Cardoso 2009). Such behavioural adaptation occurs when signal transmission through vocalisation has been masked by anthropogenic noise.

Besides anthropogenic noise, signal transmission during communication for birds can also be affected by ambient factors (Job et al. 2016; Nicholls \& Goldizen 2006; Turčoková et al. 2010) and landscape factors (i.e. distance from forest or habitat type) (Arroyo-Solís et al. 2013; Barker \& Mennill 2009; Lowry et al. 2013; Polak 2014; Sprau et al.2012). The presence of light could trigger an early start of dawn chorus of Spotless Starling (Sturnus unicolor) and House Sparrow (Passer domesticus) in the city of Seville, Spain (Arroyo-Solís et al. 2013). The early start of dawn chorus or nocturnal singing by the urban European robin (Erithacus rubecula) in Sheffield, England suggested that such behaviour occurred to reduce total time spent singing against acoustic composition taking advantage of quieter condition at night to improve signal (Fuller et al. 2007).

Besides light, temperature is capable in controlling noise level (Pudjowati et al. 2013). When the temperature increases, the molecule will vibrate faster and does the sound waves (Slabbekoorn 2004). Hasan and Badri (2016) found that weather condition (i.e. high temperature during day and moderate to low temperature at night) affected the singing and foraging activities of the House Sparrows at King Saud bin Abdul Aziz University, Saudi Arabia. In addition, in terms of landscape level factors, the pitch and temporal structure of avian vocalisation can also be influenced by habitat types through which the signal passes (Nicholls \& Goldizen 2006). Depending on soundreflecting surface such as vegetation, birds living in dense vegetated habitat tend to have songs with more slowly repeated notes and low frequency than those living in open habitats (Naguib 2003).

The Oriental Magpie Robin (Copsychus saularis), locally known as Murai Kampung, is a common songbird that can be found in many open habitats (Danmek \& Sitasuwan 2017; Davison \& Yeap 2010; Dunmak \& Sitasuwan 2007; Koli 2014; Robson 2000; Wanniarachchi \& Wijesundara 2016; Wells 2010). It is very vocal in urban areas and this makes it an ideal species to examine the effects of urban environmental factors on its acoustic communication involving flexible song traits (McCarthy et al. 2013). Previous studies done in India (Koli 2014) and Sri Lanka (Wanniarachchi \& Wijesundara 2016) only focused on various song structures of the Oriental Magpie Robin but not the effect of ambient noise toward its vocalisation. In view of the rapid urbanisation happening in Malaysia, this study examined the vocalisation of the Oriental Magpie Robin in response to anthropogenic noise and environmental factors found in the urban, suburban and rural areas in the country.

\section{MATERIALS AND METHODS}

\section{STUDY SITES}

The Oriental Magpie Robin's songs were recorded from six sampling sites, i.e. Kampung Kundur Hulu, Negeri Sembilan $\left(2^{\circ} 32^{\prime} \mathrm{N}, 102^{\circ} 2^{\prime} \mathrm{E}\right)$, Kampung Minching, Negeri Sembilan (2॰34'N, 102 $\left.{ }^{\circ}{ }^{\prime} \mathrm{E}\right)$, Universiti Putra Malaysia, Serdang, Selangor $\left(2^{\circ} 59^{\prime} \mathrm{N}, 101^{\circ} 42^{\prime} \mathrm{E}\right)$, Putrajaya Botanical Garden $\left(2^{\circ} 56^{\prime} \mathrm{N}, 101^{\circ} 41^{\prime} \mathrm{E}\right)$, Kuala Lumpur City Centre Park, Kuala Lumpur ( $3^{\circ} 09^{\prime}$ N. 101 $\left.102^{\prime} \mathrm{E}\right)$ and Bukit Jalil Technology Park, Kuala Lumpur ( $3^{\circ} 02^{\prime} \mathrm{N}$, $\left.101^{\circ} 42^{\prime} \mathrm{E}\right)$ (Figure 1).

Kampung Kundur (88.18 ha) and Kampung Minching (2.43 ha) are located at the remote area in the state of Negeri Sembilan, Peninsular Malaysia. Both villages are surrounded by farms and oil palm plantations. Universiti Putra Malaysia (715.16 ha) is located at Serdang, Selangor about $22 \mathrm{~km}$ to the south of Kuala Lumpur and it is surrounded with trees, buildings, highways and roads. Putrajaya Botanical Garden (92 ha) is located at the north of Precint 1, Putrajaya about $33 \mathrm{~km}$ to the south of Kuala Lumpur. Both Universiti Putra Malaysia and Botanical Garden Putrajaya are classified as a suburban as they are located more than $8 \mathrm{~km}$ from the city centre, i.e. Kuala Lumpur.

The 20 ha Kuala Lumpur City Centre Park is located at the centre of Kuala Lumpur, Peninsular Malaysia while Bukit Jalil Technology Park which is 280 ha is located at southern Kuala Lumpur, Peninsular Malaysia. Kuala Lumpur City Centre Park and Bukit Jalil Technology Park represented urban areas that are surrounded by many commercial buildings, main roads and residential areas. Furthermore, urban area can be defined by its dense and permanent human populations and intensive landscape planning as well as relatively high level of pollution.

\section{MEASURING VOCAL AND ENVIRONMENTAL VARIABLES}

The study was carried out between January and June 2017. All study sites were visited three times during the Oriental Magpie Robin's breeding season (Davison \& 


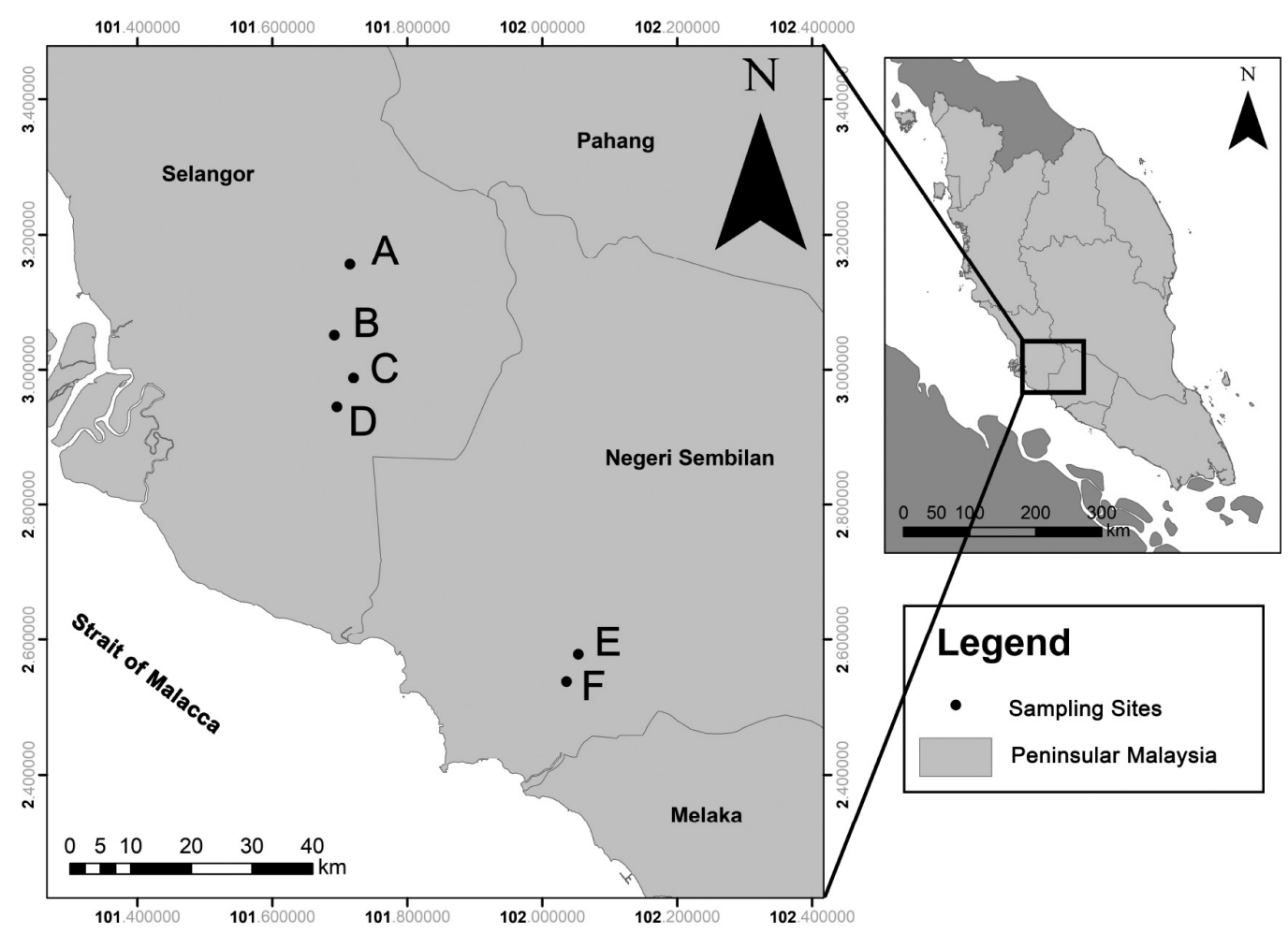

FIGURE 1. Location of study sites at rural, suburban and urban areas in Peninsular Malaysia (A = KLCC Park, Kuala Lumpur; B = Bukit Jalil Technology Park, Kuala Lumpur; C = Universiti Putra Malaysia, Selangor; D = Botanical Garden Putrajaya; E = Kampung Minching, Negeri Sembilan and F = Kampung Kundur, Negeri Sembilan)

Yeap 2010). At each site, five points with a distance of at least $100 \mathrm{~m}$ apart were established based on the presence of singing birds. The songs of the bird were recorded using a microphone (K6 Speiseadapter Powering Module) with MZW 66 foam windshield (Senheiser, Wedemark, Germany) connected to recorder (Olympus LS14 Linear PCM Recorder) in the morning and evening for 10 to 15 min at each point, when weather permitted. The surveyor (SH) approached singing birds as close as possible to obtain high quality recordings with the range of 10-50 m from the perching tree. The recordings were stored as a 16-bit wave file. Playbacks were used when there were no spontaneous calls.

Ambient level factors including temperature, relative humidity and light intensity were recorded using anemometer (Lutron LM-8010) whereas ambient noise was measured using Sound Level Meter (Pro'sKit MT4018, North America) for three times at a range of $1.2 \mathrm{~m}$ above the ground to avoid any reflecting surface (Aziz et al. 2012). Landscape level factors including distances to buildings and distance to major roads were measured using ruler tool in Google Earth Pro.

From all recordings, most songs were territorial songs and hence these songs were chosen to be analysed. Eight song parameters; low frequency (LF), high frequency (HF), mean low frequency (LF), mean high frequency (HF), mean frequency range (RF), mean length of strophe (LS), mean number of elements per strophe (EPS), and mean time interval between strophes (IS; Table 1), were derived using
Raven Pro 1.5 (Cornell Lab of Ornithology, Ithaca, New York, USA).

\section{DATA ANALYSIS}

By using SPSS software, this study used Kruskal-Wallis test to compare ambient noise and song parameters among the six sampling areas and time periods (i.e. morning and evening). Dunn's post hoc test was performed for pairwise comparison to determine which sites contributed to such a difference, if any. Box-plot graph was also used to visually compare mean low and high frequencies of the songs at six different areas. The Mann-Whitney U test was performed to test for differences in vocalisations between morning and evening sessions. Non-parametric tests were chosen after the data obtained was not normally distributed (Kolmogorov-Smirnov tests; $\mathrm{P}<0.05$ ).

In order to examine the impact of urbanization development on the Oriental Magpie Robin's vocalisation, two sets of generalized linear mixed models (GLMMs) were performed. The first set of the GLMMs examined the differences of Oriental Magpie Robin's vocalisation at different locations and time periods. The Oriental Magpie Robin's song parameters (low and high frequencies, frequency range, length of strophe, element per strophe and time interval per strophe) were fitted as dependent variable, locations (urban, suburban or rural) or time periods (morning or evening) as fixed factor and, 'sampling point within site' as a random factor. 
TABLE 1. Definition of song parameters

\begin{tabular}{ll}
\hline Song parameters & Definition \\
\hline Low frequency & Lowest frequency of a song \\
High frequency & Highest frequency of a song \\
Range of frequency & Difference between high and low frequencies \\
Length of strophe & Length of a verse in a song \\
Time interval between strophes & Time interval between verses (strophes) in a song \\
Number of elements per strophe & Number of elements in each verse (strophe) of a song \\
\hline
\end{tabular}

The second set of GLMMs examined the effect of distance to nearest main road or highway (DTR), distance to the nearest building (DTB), ambient noise $(\mathrm{N})$, temperature $(\mathrm{T})$, relative humidity (RH) and light intensity (L) on the song parameters. The song parameters were fitted as response variables while DTR, DTB, N, T, RH and L were fitted as fixed factors with sampling point as a random factor. Two sets of GLMMs used 'Imer' function with Gaussian error distribution using the lme4 package for R3.3.1 (R Core Team 2016). Predictor variables were standardized and checked for homogeneity of variances and normality of residuals prior to running GLMMs to predict changes in the Oriental Magpie Robin's vocalisation (Faraway 2006; Grueber et al. 2011). This study used Akaike Information Criteria (AICc) to rank the models and model-averaging on the best models was performed where necessary (i.e. $\Delta$ AICc $<2$, Burnham \& Anderson 2002).

\section{RESULTS}

\section{TERRITORIAL SONG STRUCTURE}

A total of 147 songs were recorded; 81 recordings in the morning and 66 in the evening survey sessions. Based on the comparison of strophes, it was found that the Oriental Magpie Robin had many song types and song elements, which can be regarded as having a large repertoire (Danmek \& Sitasuwan 2016).

\section{VARIATIONS IN ANTHROPOGENIC NOISE AT RURAL,} SUBURBAN AND URBAN AREAS

Based on Kruskal-Wallis test, ambient noise at the six sampling sites were significantly different $\left(\chi^{2}=112.412\right.$, $\mathrm{P}<0.001)$. The low frequency of songs at these sites was significantly different $\left(\chi^{2}=39.792, \mathrm{P}<0.05\right)$. The low frequency of songs increased from rural Sites $\mathrm{E}$ and F) to suburban (Sites C and D) and followed by urban areas (Sites A and B). However, there was no significant difference in high frequency of songs at the six sampling sites $\left(\chi^{2}=2.729, \mathrm{P}>0.05\right)$.

Results of Kruskal-Wallis test also indicated that there were significant differences in IS at the six sampling areas. Pairwise comparison done on the time interval between strophes indicated that IS at Site F (i.e. a rural area) was significantly differed from Site $\mathrm{D}$ that belongs to suburban area $(\mathrm{P}<0.05)$. However, there is no evidence of different for the other pairs. Mann-Whitney U-test showed that low frequency of songs recorded in the morning was significantly higher than that in the evening $(P<0.05)$.

\section{EFFECTS OF URBAN ENVIRONMENTAL FACTORS}

GLMMs analysis showed that there were single and interaction effects occurred between environmental variables and song parameters. The Oriental Magpie Robin's low frequency was negatively related to distance to road (mean effect size $=-81.81$, CIs $=-127.78$ to -35.83 ) with no interactions. The low frequency of songs had significantly decreased at sites that were far away from road. The high frequency of the Oriental Magpie Robin's vocalisation decreased with increasing the distance to building (mean effect size, $\mathrm{E}=-$ 120.7, CIs $=-218.4$ to -23.1 ). There was an interaction effect between noise and humidity as well as between noise and temperature on high frequency.

The frequency range of Oriental Magpie Robin's vocalisation was not affected by any single effect but affected by interaction effects. The frequency range of songs seemed to decrease at locations that were noisy, hotter and more humid. The length of strophe of the Oriental Magpie Robin's songs were likely reduced at locations with higher temperature and noise, which was shown in many of the best models derived from GLMMs (Table 2). The number of elements per strophe was affected by humidity. The number of elements per strophe increased with increasing humidity (mean effect size, $\mathrm{E}=1.20$, CIs $=-0.18$ to 2.01 ).

There were also three positive interaction effects between distances to building and road; distance to road and temperature; and humidity and temperature on Oriental Magpie Robin's time interval between strophes. This implied that time interval between strophes increased at sites located furthest away from road or highway, and buildings, with colder and higher humidity environment. GLMMs also showed a negative interaction between noise and humidity on time interval between strophes, suggesting that the time interval between strophes reduced at sites with high humidity and low ambient noise.

\section{DISCUSSION}

\section{SONG STRUCTURE OF ORIENTAL MAGPIE ROBIN}

The low frequency obtained from the Oriental Magpie Robins living in urban areas was found to be higher than those of the suburban and rural areas. Urban areas 
TABLE 2. Generalized linear mixed models (GLMM, based on AICc) for determining Oriental Magpie Robins's songs at urban, suburban and rural areas. All models were generated based on six variables (i.e. DTR, DTB, N, T, RH and L and, RH) limited to 2-way interactions. Best models with $\Delta \mathbf{i}<2$ are presented. DTR $=$ distance to nearest highway or main road, DTB $=$ distance to the nearest building, $\mathrm{N}=$ ambient noise, $\mathrm{T}=$ temperature, $\mathrm{L}=$ light intensity, $\mathrm{RH}=$ relative humidity, Log-lik $=$ natural logarithm of likelihood function, $\mathrm{AICc}=$ measure of the relative quality of a model with small sample sizes, $\Delta \mathrm{i}=$ difference to a model with the lowest AIC model, $\mathrm{e}^{(-\Delta \mathrm{i} / 2)}=$ relative likelihood, wi $=$ AIC weight, $\mathrm{R}_{\mathrm{GLMM}(\mathrm{m})}^{2}=$ variance explained by fixed factors, and $\mathrm{R}_{\mathrm{GLMM}(\mathrm{c})}^{2}=$ variance explained by fixed and random factors

\begin{tabular}{|c|c|c|c|c|c|c|c|}
\hline Model & Log-lik & $\mathrm{AICc}$ & $\Delta \mathrm{i}$ & $\mathrm{e}^{(-\boldsymbol{\Delta} / 2)}$ & wi & $\mathrm{R}_{\text {GLMM(m) }}^{2}$ & $\mathrm{R}_{\mathrm{GLMM}(\mathrm{c})}^{2}$ \\
\hline \multicolumn{8}{|l|}{ Mean of low frequency } \\
\hline Null & -1008.4 & 2024.7 & - & - & - & 0.000 & 0.255 \\
\hline $\mathrm{DTR}+\mathrm{T}$ & -999.9 & 2012.4 & 0.00 & 1.00 & 0.728 & 0.144 & 0.272 \\
\hline $\mathrm{DTR}+\mathrm{RH}$ & -999.9 & 2012.4 & 0.04 & 0.98 & 0.025 & 0.147 & 0.274 \\
\hline $\mathrm{DTR}+\mathrm{RH}+\mathrm{DTR} * \mathrm{RH}$ & -999.2 & 2013.2 & 0.75 & 0.69 & 0.025 & 0.157 & 0.288 \\
\hline DTB+DTR+RH & -999.6 & 2014.0 & 1.60 & 0.45 & 0.017 & 0.141 & 0.280 \\
\hline DTB+DTR+T & -999.6 & 2014.1 & 1.67 & 0.43 & 0.011 & 0.137 & 0.277 \\
\hline $\mathrm{DTR}+\mathrm{T}+\mathrm{DTR} * \mathrm{~T}$ & -999.7 & 2014.1 & 1.71 & 0.43 & 0.011 & 0.147 & 0.278 \\
\hline $\mathrm{DTR}+\mathrm{N}+\mathrm{T}$ & -999.8 & 2014.3 & 1.91 & 0.38 & 0.011 & 0.169 & 0.249 \\
\hline $\mathrm{DTR}+\mathrm{N}+\mathrm{RH}$ & -999.9 & 2014.4 & 1.99 & 0.37 & 0.011 & 0.170 & 0.252 \\
\hline $\mathrm{DTR}+\mathrm{RH}+\mathrm{T}$ & -999.8 & 2014.4 & 1.99 & 0.37 & 0.010 & 0.147 & 0.273 \\
\hline \multicolumn{8}{|l|}{ Mean of high frequency } \\
\hline Null & -1152.7 & 2313.4 & - & - & - & 0.000 & 0.029 \\
\hline $\mathrm{DTB}+\mathrm{N}+\mathrm{RH}+\mathrm{T}+\mathrm{N} * \mathrm{~T}$ & -1141.8 & 2305.1 & 0.00 & 1.00 & 0.044 & 0.050 & 0.056 \\
\hline $\mathrm{DTB}+\mathrm{DTR}+\mathrm{N}+\mathrm{RH}+\mathrm{T}+\mathrm{N} * \mathrm{RH}+\mathrm{N} * \mathrm{~T}$ & -1141.5 & 2306.9 & 1.78 & 0.41 & 0.018 & 0.144 & 0.144 \\
\hline $\mathrm{DTB}+\mathrm{L}+\mathrm{N}+\mathrm{RH}+\mathrm{N} * \mathrm{RH}+\mathrm{N} * \mathrm{~T}$ & -1141.6 & 2307.1 & 1.98 & 0.37 & 0.016 & 0.143 & 0.143 \\
\hline \multicolumn{8}{|l|}{ Mean range of frequency } \\
\hline Null & -1064.8 & 2137.6 & - & - & - & 0.000 & 0.029 \\
\hline $\mathrm{DTB}+\mathrm{DTR}+\mathrm{N}+\mathrm{RH}+\mathrm{T}$ & -1051.5 & 2127.0 & 0.00 & 1.00 & 0.020 & 0.104 & 0.126 \\
\hline $\mathrm{DTB}+\mathrm{N}+\mathrm{RH}+\mathrm{T}$ & -1053.0 & 2127.6 & 0.60 & 0.74 & 0.015 & 0.094 & 0.116 \\
\hline DTB+ DTR+ N+ RH+T+DTR*T & -1050.8 & 2127.9 & 0.90 & 0.64 & 0.013 & 0.105 & 0.128 \\
\hline $\mathrm{DTB}+\mathrm{DTR}+\mathrm{N}+\mathrm{RH}+\mathrm{T}+\mathrm{DTR} * \mathrm{RH}$ & -1050.9 & 2128.1 & 1.16 & 0.56 & 0.011 & 0.110 & 0.134 \\
\hline $\mathrm{DTR}+\mathrm{N}+\mathrm{RH}+\mathrm{T}$ & -1053.4 & 2128.5 & 1.47 & 0.48 & 0.009 & 0.090 & 0.122 \\
\hline $\mathrm{DTB}+\mathrm{DTR}+\mathrm{N}+\mathrm{RH}+\mathrm{T}+\mathrm{DTB} * \mathrm{RH}$ & -1051.1 & 2128.6 & 1.57 & 0.46 & 0.009 & 0.110 & 0.134 \\
\hline DTB+ DTR+ N+ RH+T+DTB*T & -1051.2 & 2128.8 & 1.79 & 0.41 & 0.008 & 0.110 & 0.131 \\
\hline $\mathrm{DTB}+\mathrm{DTR}+\mathrm{L}+\mathrm{N}+\mathrm{RH}+\mathrm{T}$ & -1051.3 & 2128.8 & 1.85 & 0.40 & 0.008 & 0.104 & 0.127 \\
\hline $\mathrm{DTB}+\mathrm{DTR}+\mathrm{N}+\mathrm{RH}+\mathrm{T}+\mathrm{DTB} * \mathrm{~N}$ & -1051.3 & 2128.9 & 1.89 & 0.39 & 0.008 & 0.118 & 0.118 \\
\hline \multicolumn{8}{|l|}{ Mean length of strophe } \\
\hline NULL & -118.5 & 245.0 & - & - & - & 0.000 & 0.057 \\
\hline $\mathrm{L}+\mathrm{T}+\mathrm{L} * \mathrm{~T}$ & -113.2 & 241.3 & 0.00 & 1.00 & 0.020 & 0.070 & 0107 \\
\hline $\mathrm{DTB}+\mathrm{L}+\mathrm{T}+\mathrm{L} * \mathrm{~T}$ & -112.5 & 242.0 & 0.73 & 0.69 & 0.014 & 0.082 & 0.114 \\
\hline $\mathrm{DTB}+\mathrm{RH}$ & -114.9 & 242.4 & 1.11 & 0.57 & 0.011 & 0.050 & 0.091 \\
\hline $\mathrm{L}+\mathrm{N}+\mathrm{T}+\mathrm{L} * \mathrm{~T}$ & -112.8 & 242.7 & 1.40 & 0.50 & 0.010 & 0.075 & 0.117 \\
\hline $\mathrm{DTB}+\mathrm{L}+\mathrm{N}+\mathrm{T}+\mathrm{L} * \mathrm{~T}$ & -111.8 & 242.9 & 1.63 & 0.44 & 0.009 & 0.090 & 0.127 \\
\hline RH & -116.3 & 242.9 & 1.67 & 0.43 & 0.009 & 0.030 & 0.117 \\
\hline $\mathrm{L}+\mathrm{RH}+\mathrm{T}+\mathrm{L} * \mathrm{RH}+\mathrm{L} * \mathrm{~T}$ & -111.9 & 243.1 & 1.80 & 0.41 & 0.008 & 0.089 & 0.117 \\
\hline $\mathrm{L}+\mathrm{RH}+\mathrm{T}+\mathrm{L} * \mathrm{~T}$ & -113.0 & 243.1 & 1.83 & 0.40 & 0.008 & 0.073 & 0.102 \\
\hline DTB+DTR+RH & -114.2 & 243.2 & 1.94 & 0.38 & 0.008 & 0.061 & 0.082 \\
\hline \multicolumn{8}{|l|}{ Mean element per strophe } \\
\hline NULL & -334.5 & 677.0 & - & - & - & 0.000 & 0.071 \\
\hline $\mathrm{DTB}+\mathrm{N}+\mathrm{RH}+\mathrm{T}$ & -326.5 & 670.0 & 0.00 & 1.00 & 0.016 & 0.107 & 0.157 \\
\hline $\mathrm{DTB}+\mathrm{RH}+\mathrm{T}$ & -327.8 & 670.3 & 0.37 & 0.83 & 0.013 & 0.091 & 0.146 \\
\hline $\mathrm{DTB}+\mathrm{N}+\mathrm{RH}$ & -328.1 & 671.0 & 1.05 & 0.59 & 0.009 & 0.086 & 0.148 \\
\hline $\mathrm{RH}+\mathrm{T}$ & -329.3 & 671.1 & 1.16 & 0.56 & 0.009 & 0.068 & 0.143 \\
\hline $\mathrm{DTB}+\mathrm{N}+\mathrm{RH}+\mathrm{T}+\mathrm{N} * \mathrm{RH}$ & -326.1 & 671.6 & 1.61 & 0.45 & 0.007 & 0.111 & 0.167 \\
\hline $\mathrm{DTB}+\mathrm{N}+\mathrm{RH}+\mathrm{T}+\mathrm{RH}{ }^{*} \mathrm{~T}$ & -326.1 & 671.6 & 1.64 & 0.44 & 0.007 & 0.111 & 0.157 \\
\hline $\mathrm{DTB}+\mathrm{RH}$ & -329.6 & 671.7 & 1.76 & 0.41 & 0.007 & 0.068 & 0.136 \\
\hline $\mathrm{DTB}+\mathrm{N}+\mathrm{RH}+\mathrm{T}+\mathrm{N} * \mathrm{~T}$ & -326.3 & 671.8 & 1.85 & 0.40 & 0.006 & 0.110 & 0.165 \\
\hline $\mathrm{N}+\mathrm{RH}+\mathrm{T}$ & -328.5 & 671.9 & 1.90 & 0.39 & 0.006 & 0.078 & 0.153 \\
\hline
\end{tabular}


Continued TABLE 2.

\begin{tabular}{|c|c|c|c|c|c|c|c|}
\hline Model & Log-lik & AICc & $\Delta \mathrm{i}$ & $\mathrm{e}^{(-\mathbf{\Delta} / 2)}$ & wi & $\mathrm{R}_{\text {GLMM(m) }}^{2}$ & $\mathrm{R}_{\text {GLMM(c) }}^{2}$ \\
\hline \multicolumn{8}{|l|}{ Mean time interval per strophe } \\
\hline NULL & -346.8 & 701.5 & - & - & - & 0.000 & 0.054 \\
\hline $\begin{array}{l}\mathrm{DTB}+\mathrm{T}+\mathrm{N}+\mathrm{RH}+\mathrm{DTB} * \mathrm{DTR}+\mathrm{DTB} * \mathrm{RH}+\mathrm{DTB} * \mathrm{~T}+\mathrm{DTR} * \mathrm{RH}+\mathrm{D} \\
\mathrm{TR} * \mathrm{~T}+\mathrm{N} * \mathrm{~T}+\mathrm{RH} * \mathrm{~T}\end{array}$ & -330.9 & 698.1 & 0.00 & 1.00 & 0.020 & 0.201 & 0.210 \\
\hline $\begin{array}{l}\mathrm{DTB}+\mathrm{T}+\mathrm{N}+\mathrm{RH}+\mathrm{DTB} * \mathrm{DTR}+\mathrm{DTB} * \mathrm{RH}+\mathrm{DTR} * \mathrm{RH}+\mathrm{DTR} * \mathrm{~T}+ \\
\mathrm{N} * \mathrm{~T}+\mathrm{RH} * \mathrm{~T}\end{array}$ & -332.3 & 698.3 & 0.21 & 0.90 & 0.018 & 0.186 & 0.191 \\
\hline $\begin{array}{l}\mathrm{DTB}+\mathrm{T}+\mathrm{L}+\mathrm{N}+\mathrm{RH}+\mathrm{DTB} * \mathrm{DTR}+\mathrm{DTB} * \mathrm{RH}+\mathrm{DTB} * \mathrm{~T}+\mathrm{DTR} * \mathrm{RH} \\
+\mathrm{DTR} * \mathrm{~T}+\mathrm{N} * \mathrm{~T}+\mathrm{RH} * \mathrm{~T}\end{array}$ & -330.3 & 699.3 & 1.16 & 0.56 & 0.011 & 0.208 & 0.199 \\
\hline $\begin{array}{l}\mathrm{DTB}+\mathrm{T}+\mathrm{L}+\mathrm{N}+\mathrm{RH}+\mathrm{DTB} * \mathrm{DTR}+\mathrm{DTB} * \mathrm{RH}+\mathrm{DTR} * \mathrm{RH}+\mathrm{DTR} * \\
\mathrm{~T}+\mathrm{N} * \mathrm{~T}+\mathrm{RH} * \mathrm{~T}\end{array}$ & -331.6 & 699.5 & 1.39 & 0.50 & 0.010 & 0.163 & 0.199 \\
\hline $\mathrm{DTB}+\mathrm{T}+\mathrm{N}+\mathrm{RH}+\mathrm{DTB} * \mathrm{DTR}+\mathrm{DTB} * \mathrm{RH}+\mathrm{N} * \mathrm{RH}+\mathrm{N} * \mathrm{~T}+\mathrm{RH} * \mathrm{~T}$ & -334.4 & 700.0 & 1.89 & 0.39 & 0.008 & 0.163 & 0.167 \\
\hline $\begin{array}{l}\mathrm{DTB}+\mathrm{T}+\mathrm{N}+\mathrm{RH}+\mathrm{DTB} * \mathrm{DTR}+\mathrm{DTB} * \mathrm{~N}+\mathrm{DTB} * \mathrm{RH}+\mathrm{DTR} * \mathrm{RH}+ \\
\mathrm{DTR} * \mathrm{~T}+\mathrm{N} * \mathrm{~T}+\mathrm{RH} * \mathrm{~T}\end{array}$ & -331.9 & 700.0 & 1.89 & 0.39 & 0.008 & 0.191 & 0.195 \\
\hline $\mathrm{DTB}+\mathrm{N}+\mathrm{RH}+\mathrm{DTB} * \mathrm{~N}+\mathrm{DTB} * \mathrm{RH}+\mathrm{N} * \mathrm{RH}+\mathrm{N} * \mathrm{~T}+\mathrm{RH} * \mathrm{~T}$ & -335.6 & 700.0 & 1.90 & 0.39 & 0.008 & 0.145 & 0.171 \\
\hline $\mathrm{DTB}+\mathrm{N}+\mathrm{RH}+\mathrm{DTB} * \mathrm{RH}+\mathrm{N} * \mathrm{RH}+\mathrm{N} * \mathrm{~T}+\mathrm{RH} * \mathrm{~T}$ & -336.9 & 700.1 & 1.98 & 0.37 & 0.008 & 0.132 & 0.175 \\
\hline $\begin{array}{l}\mathrm{DTB}+\mathrm{T}+\mathrm{N}+\mathrm{RH}+\mathrm{DTB} * \mathrm{DTR}+\mathrm{DTB} * \mathrm{~N}+\mathrm{DTB} * \mathrm{RH}+\mathrm{DTB} * \mathrm{~T}+\mathrm{DT} \\
\mathrm{R} * \mathrm{RH}+\mathrm{DTR} * \mathrm{~T}+\mathrm{N} * \mathrm{~T}+\mathrm{RH} * \mathrm{~T}\end{array}$ & -330.7 & 700.1 & 1.98 & 0.37 & 0.008 & 0.204 & 0.212 \\
\hline
\end{tabular}

apparently recorded higher level of ambient noise than suburban and rural areas. However, there was no significant difference in the high frequency of songs recorded at the six sampling areas. It has been speculated that species with low frequency are more sensitive to anthropogenic noise (Hu \& Cardoso 2009) and the low frequency of the songs can be easily masked by noise compared to that with high frequency (Brumm \& Slabbekoorn 2005). Low frequency of songs has the potential to convey a message and transmit well through vegetation (Blumenrath et al. 2004). A difference in low frequency was also observed in the morning with higher ambient noise than the evening. As compared to previous studies (Koli 2014; Wanniarachchi $\&$ Wijesundara 2016), our study showed that the low and high frequencies obtained were lower. The range of frequency of the Oriental Magpie Robin found in our study was lower, but higher in time interval between strophes than those found in Thailand (Danmek \& Sitasuwan 2016). This findings suggesting that the Oriental Magpie Robins at some areas in Malaysia may sing slower than those in Thailand. The length of strophe for the Oriental Magpie Robins' songs at some areas in Malaysia (2.08 s) was also slightly higher than those birds in Thailand (2.07 s, 2007; $1.90 \mathrm{~s}, 2017)$, implying that birds in Malaysia may sing longer than the ones in Thailand. Similarly, the number of elements per strophe in the Oriental Magpie Robin's song in Malaysia (7.35 elements) was slightly higher than the ones in Thailand (6.7 elements, 2007; 6.84 elements, 2017). This implies that birds in Malaysia have more complex song structure compared to those in Thailand.

The difference in song frequency and structure produced by the Oriental Magpie Robins found in the current study in Malaysia and previous studies in Sri Lanka (i.e. a suburban area), Thailand (a rural area) and
India (a wildlife sanctuary) may be caused by different habitat structure which can be a main factor in shaping the bird songs (Boncoraglio \& Saino 2007; Hill et al. 2018). The acoustic adaptation hypothesis predicts that low frequency and long elements are linked to habitat with complex vegetation structure while high frequency and short elements are likely to be obtained in habitat with herbaceous coverage (Morton 1975). Furthermore, there may be a difference in noise level at sampled areas in the current study that caused the Oriental Magpie Robin to produce song frequencies and structure that are different from other studies.

\section{VOCAL PLASTICITY OF ORIENTAL MAGPIE ROBIN}

GLMMs showed that there were several single and interaction effects occurred between variables (i.e. noise, temperature, humidity, distance to road and distance to building) and song parameters (e.g. low frequency, length of strophe, time interval between strophes and number of elements per strophe). With respect to single effect, the birds observed tend to reduce the low and high frequencies of their songs at sites that were far away from road and buildings, respectively. Other than that, our study also showed that the Oriental Magpie Robin's song structure can be more complex at sites with high humidity.

There was an interaction effect between noise and relative humidity as well as with temperature on HF, suggesting that Oriental Magpie Robin had lower high frequency at locations that were noisy and hotter coupled with high humidity. The RF decreased at locations that were noisy, hotter with high humidity. In terms of Oriental Magpie Robin's singing, the LS was likely to be reduced at locations with higher temperature and noise. There were also three positive interaction effects between distance 
to buildings and distance to road; distance to road and temperature, and relative humidity and temperature on the time interval between strophes. The time interval between strophes found in current study was also different from that of Hill et al. (2018) that compared songs of the same species at urban and rural areas from seven countries (i.e. Bangladesh, India, Malaysia, Nepal, Singapore, Sri Lanka and Thailand). Hill et al. (2018) found that urban environment may cause the Oriental Magpie Robin to produce longer and slower songs to maximize the efficiency of transmission in urban habitat. In contrast, this study found that individuals at sites involved in current study in Malaysia sang slower at sites with rural area characteristics (i.e. further from road and building, and colder with high humidity). Such a difference implies that the Oriental Magpie Robin is capable to alter their vocalisation based on the surrounding environment.

\section{CONCLUSION}

Present study showed that low frequency of songs was a significant song parameter for the Oriental Magpie Robin in response to ambient noise which is higher in urban areas. In our study, urban environmental factors such as noise, temperature and relative humidity had led to both single effect and interaction effects towards the Oriental Magpie Robin's song parameters such as low frequency, length of strophe, time interval between strophes and number of elements per strophe. The results imply that the Oriental Magpie Robins in current study have adapted in different habitat conditions by regulating and altering their frequency of songs. As supported by Boncoraglio and Saino (2007), Hasan and Badri (2016), Hill et al. (2018), and Martin et al. (2000), environmental condition has been shown to affect the birds' vocalisations by driving the production of different song structures. This vocal alteration and adjustment are important in ensuring the efficiency in transmission of songs and it is a form of behavioural adaptation in response to environmental condition. All these may explain the reasons why Oriental Magpie Robin is known as a common urban bird species which is less susceptible to urbanisation and their vocal plasticity has been demonstrated in this study.

\section{ACKNOWLEDGEMENTS}

Our research was funded by Universiti Putra Malaysia through the Putra Grant (Project No. GP-IPS/2017/9540100). We thank the KLCC Park Management for the permission to access KLCC Park. We sincerely thank Mohd Shafiq bin Mohd Hanafi for his assistance in the field and Jamhuri bin Jamaluddin for his assistance with the maps.

\section{REFERENCES}

Arroyo-Solís, A., Castillo, J.M., Figueroa, E., López-Sánchez, J.L. \& Slabbekoorn, H. 2013. Experimental evidence for an impact of anthropogenic noise on dawn chorus timing in urban birds. Journal of Avian Biology 44: 288-296.
Aziz, S.Q., Lulusi, Asaari, F.A.H., Ramli, N.A., Aziz, H.A., Mojiri, A. \& Umar, M. 2012. Assessment of traffic noise pollution in Bukit Mertajam, Malaysia and Erbil City, Iraq. Caspian Journal of Applied Sciences Research 1: 1-11.

Barker, N.K.S. \& Mennill, D.J. 2009. Song perch height in Rufous-and-White Wrens: Does behaviour enhance effective communication in a tropical forest? Ethology 115: 897-904.

Bermúdez-Cuamatzin, E., Ríos-Chelén, A.A., Gil, D. \& Garcia, C.M. 2009. Strategies of song adaptation to urban noise in the House Finch: Syllable pitch plasticity or differential syllable use? Behaviour 146: 1269-1286.

Blumenrath, S.H., Dabelsteen, T. \& Pedersen, S.B. 2004. Being inside nest boxes: Does it complicate the receiving conditions for Great Tit Parus major females? Bioacoustics 14: 209-223.

Boncoraglio, G. \& Saino, N. 2007. Habitat structure and the evolution of bird song: a meta-analysis of the evidence for the acoustic adaptation hypothesis. Functional Ecology 21: 134-142.

Brumm, H. \& Slabbekoorn, H. 2005. Acoustic communication in noise. Advances in the Study of Behaviour 35: 151-209.

Mendes, S., Colino-Rabanal, V.J. \& Peris, S.J. 2011. Bird song variations along an urban gradient: the case of the European Blackbird (Turdus merula). Landscape and Urban Planning 99: 51-57.

Dunmak, A. \& Sitasuwan, N. 2007. Song dialect of Oriental Magpie Robin (Copsychus saularis) in Northern Thailand. The Natural History Journal of Chulalongkorn University 7(2): 145-153.

Danmek, A. \& Sitasuwan, N. 2016. Repertoire and geographical variation in song of Oriental Magpie Robin (Copsychus saularis) in northern Thailand. Current Science 111(8): 1400-1406.

Danmek,A. \& Sitasuwan, N. 2017. Persistence and alteration of the song structure of the Oriental Magpie Robin (Copsychus saularis) in some areas of Northern Thailand. Chiang Mai Journal of Science 44(2): 478-486.

Davison, G.W.H. \& Yeap, C.A. 2010. A Naturalist's Guide to the Birds of Malaysia Including Sabah and Sarawak. Oxford: John Beaufoy Publishing.

Department of Environment (DOE). 2007. The Planning Guidelines for Environmental Noise Limits and Control. https://www.doe.gov.my/portalv1/en/info-umum/theplanning-guidelines-for-environmental-noise-limits-andcontrol/272.

Faeth, S.H., Bang, C. \& Saari, S. 2011. Urban biodiversity: Patterns and mechanisms. Annals of the New York Academy of Sciences 1223: 69-81.

Faraway, J.J. 2006. Extending the Linear Model with R: Generalized Linear, Mixed Effects and Nonparametric Regression Models. Boca Raton: Chapman and Hall.

Francis, C.D., Ortega, C.P. \& Cruz, A. 2010. Vocal frequency change reflects different responses to anthropogenic noise in two suboscine tyrant flycatchers. Proceedings of the Royal Society of London Series B 278(1714): 2025-2031.

Fuller, R.A., Warren, P.H. \& Gaston, K.J. 2007. Daytime noise predicts nocturnal singing in urban robins. Biology Letters 3(4): 368-370.

Grueber, C.E., Nakagawa, S., Laws, R.J. \& Jamieson, I.G. 2011. Multimodel inference in ecology and evolution: Challenges and solutions. Journal of Evolutionary Biology 24(4): 699711.

Halfwerk, W., Holleman, L.J.M., Lessells, C.M. \& Slabbekoorn, H. 2011. Negative impact of traffic noise on avian 
reproductive success. Journal of Applied Ecology 48(1): 210-219.

Halfwerk, W. \& Slabbekoorn, H. 2009. A behavioural mechanism explaining noise-dependent frequency use in urban birdsong. Animal Behaviour 78(6): 1301-1307.

Hasan, A.R. \& Nair, P.L. 2014. Urbanization and growth of metropolitan centres in Malaysia. Malaysian Journal of Economic Studies 51(1): 87-101.

Hasan, N.M. \& Badri, M. 2016. Effect of ambient temperature on dawn chorus of house sparrows. Environment and Ecology Research 4(3): 161-168.

Hill, S.D., Aryal, A., Pawley, M.D.M. \& Ji, W. 2018. So much for the city: Urban-rural song variation in a widespread Asiatic songbird. Integrative Zoology 13(2): 194-205.

Hu, Y. \& Cardoso, G.C. 2009. Are bird species that vocalize at higher frequencies preadapted to inhabit noisy urban areas? Behavioural Ecology 20(6): 1268-1273.

Job, J.R., Kohler, S.L. \& Gill, S.A. 2016. Song adjustments by an open habitat bird to anthropogenic noise, urban structure and vegetation. Behavioural Ecology 27(6): 1734-1744.

Koli, V.K. 2014. Morning territorial calls of male Oriental Magpie Robin (Copsychus saularis). TAPROBANICA: The Journal of Asian Biodiversity 6(1): 60-62.

Lowry, H., Lill, A. \& Wong, B.B. 2013. Behavioural responses of wildlife to urban environments. Biological Reviews 88(3): 537-549.

Luther, D.A., Phillips, J. \& Derryberry, E.P. 2016. Not so sexy in the city: Urban birds adjust songs to noise but compromise vocal performance. Behavioural Ecology 27(1): 332-340.

Martin, S.D., Gray, D.A. \& Cade, W.H. 2000. Fine-scale temperature effects on cricket calling song. Canadian Journal of Zoology 78(5): 706-712.

McCarthy, A.H., Potvin, D.A., Aslam, T., Bartlett, R., Beebe, S., Bennet, J., Hitchcock, D.J. \& Tee, M. 2013. Differences between the songs of rural and urban Australian Magpies (Gymnorhina tibicen) and the potential consequences for territorial interactions. Notornis 60(2): 143-150.

McKinney, M.L. 2006. Urbanization as a major cause of biotic homogenization. Biological Conservation 127(3): 247-260.

Morton, E.S. 1975. Ecological sources of selection on avian sounds. The American Naturalist 109(965): 17-34.

Naguib, M. 2003. Reverberation of rapid and slow trills: Implications for signal adaptations to long range communication. Journal of the Acoustical Society of America 113: $1749-1756$.

Nicholls, J.A. \& Goldizen, A.W. 2006. Habitat type and density influence vocal signal design in Satin Bowerbirds. Journal of Animal Ecology 75(2): 549-558.

Polak, M. 2014. Relationship between traffic noise levels and song perch height in a common passerine bird. Transportation Research Part D 30: 72-75.

Potvin, D.A., Parris, K.M. \& Mulder, R.A. 2011. Geographically pervasive effects of urban noise on frequency and syllable rate of songs and calls in Silvereyes (Zosterops lateralis). Proceedings of the Royal Society Series B 278(1717): 24642469.

Puan, C.L., Yeong, K.L., Ong, K.W., Fauzi, M.I.A., Yahya, M.S \& Khoo, S.S. 2019. Influence of landscape matrix on urban bird abundance: Evidence from Malaysian citizen science data. Journal of Asia-Pacific Biodiversity 12(3): 369-375.

Pudjowati, U.R., Yanuwiyadi, B., Sulistiono, R. \& Suyadi. 2013. Estimation of noise reduction by different vegetation type as a noise barrier: A survey in highway along Waru-Sidoarjo in
East Java, Indonesia. Research Inventy: International Journal of Engineering and Science 2(11): 20-25.

Robson, C. 2000. A Field Guide to the Birds of South-East Asia. London: New Holland. p. 504.

Seress, G. \& Liker, A. 2015. Habitat urbanization and its effects on birds. Acta Zoologica Academiae Scientiarum Hungaricae 61(4): 373-408.

Slabbekoorn, H. 2004. Singing in the wild: The ecology of birdsong. In Nature's Music: The Science of Birdsong, edited by Marler, P. \& Slabbekoorn, H. San Diego: Elsevier Academic Press.

Sprau, P., Roth, T., Naguib, M. \& Amrhein, V. 2012. Communication in the third dimension: Song perch height of rivals affects singing response in Nightingales. PLOS ONE 7: 1-6. https://doi.org/10.1371/journal.pone.0032194.

Turčoková,L., Osiejuk, T.S., Pavel, V., Glapan, J. \& Petrusková, T. 2010. Song divergence of two Bluethroat subspecies (Luscinia s. svecica and L. s. cyanecula). Ornis Fennica 87: 168-179.

Wanniarachchi, S. \& Wijesundara, C.S. 2016. The repertoire and structure of vocalisations of the Southern Magpie Robin (Copsychus saularis ceylonensis) in the Kandy region, Sri Lanka. Ceylon Journal of Science 45: 47-54.

Wells, D.R. 2010. The birds of the Thai-Malay Peninsula. The Condor. 110(3): 589-590.

World Health Organization (WHO). 1999. Guidelines for Community Noise. World Health Organization. https://apps. who.int/iris/handle/10665/66217.

Shafinaz Hanafi \& Chong Leong Puan*

Faculty of Forestry

Universiti Putra Malaysia

43400 UPM Serdang, Selangor Darul Ehsan Malaysia

Chong Leong Puan*

Institute of Tropica Forestry and Forest Products (INTROP)

Universiti Putra Malaysia

43400 UPM Serdang, Selangor Darul Ehsan

Malaysia

Chong Leong Puan*

Biodiversity Unit

Institute of Bioscience

Universiti Putra Malaysia

43400 UPM Serdang, Selangor Darul Ehsan

Malaysia

Sreetheran Maruthaveeran

Faculty of Design and Architecture

Universiti Putra Malaysia

43400 UPM Serdang, Selangor Darul Ehsan

Malaysia

Kok Loong Yeong

Leverhulme Centre for Climate Change Mitigation (LC3M)

University of Sheffield

Department of Animal and Plant Sciences

Alfred Denny Building, Western Bank

Sheffield, S10 2TN

United Kingdom 
Kok Loong Yeong

South East Asia Rainforest Research Partnership

Danum Valley Field Centre

91112, Lahad Datu, Sabah

Malaysia
*Corresponding author; email: chongleong@upm.edu.my

Received: 6 December 2018

Accepted: 29 July 2019 